\title{
Menyelami Novel Kiai Ibrahim dan Tempat-Tempat Ibadat Karya Akhmad Dimyati serta Relevansinya terhadap Pendidikan Karakter
}

\author{
Udi Sukrama ${ }^{1)}$ \\ Universitas Indraprasta PGRI \\ Jalan Nangka No. 58 C/TB. Simatupang, Tanjung Barat, Jakarta Selatan 12530 \\ Mamik Suendarti' \\ Universitas Indraprasta PGRI \\ Jalan Nangka No. 58 C/TB. Simatupang, Tanjung Barat, Jakarta Selatan 12530 \\ Bambang Sumadyo ${ }^{3)}$
Universitas Indraprasta PGRI \\ Jalan Nangka No. 58 C/TB. Simatupang, Tanjung Barat, Jakarta Selatan 12530 \\ udisukrama@gmail.com ${ }^{1)}$
}

\begin{abstract}
This study aims to determine the value of character education contained in the novel Kiai Ibrahim dan Tempat-Tempat Ibadat by Akhmad Dimyati and its relevance to learning in high school. This research use desciptive qualitative approach. Based on the results of research on the novel Kiai Ibrahim dan Tempat-Tempat Ibadat by Akhmad Dimyati, namely: 1) The value of character education in the novel Kiai Ibrahim dan Tempat-Tempat Ibadat by Akhmad Dimyati can be divided into four criteria. First, the value of character education that reflects the relationship between humans and God, which includes values; pray, have faith, and repent are categorized as values of religious character education. Second, the value of character education that reflects the human relationship with himself, which includes values; disciplined, democratic, creative, hard work, and a national spirit. Third, the value of character education that reflects the relationship between humans and society, which includes values; honest, curiosity, social care, tolerance, responsibility, communicative, disciplined, and creative. Fourth, the value of character education that reflects the relationship between humans and the environment, which includes being communicative and caring for the environment. 2) There is the relevance of the novel Kiai Ibrahim and Akhmad Dimyati's Places of Worship on learning material in schools, so that it can be used as reference material in literacy learning material literacy activities for high school students.
\end{abstract}

Keywords: Novel Kiai Ibrahim dan Tempat-Tempat Ibadat, character education, literature learning.

\begin{abstract}
Abstrak
Penelitian ini bertujuan untuk mengetahui nilai pendidikan karakter yang terdapat di dalam novel Kiai Ibrahim dan Tempat-Tempat Ibadat karya Akhmad Dimyati dan relevansinya terhadap pembelajaran di SMA. Penelitian ini menggunakan pendekatan deskriptif kualitatif. Berdasarkan hasil penelitian terhadap novel Kiai Ibrahim dan Tempat-Tempat Ibadat Karya Akhmad Dimyati yaitu: 1) Nilai pendidikan karakter dalam novel Kiai Ibrahim dan Tempat-Tempat Ibadat Karya Akhmad Dimyati dibedakan menjadi empat kriteria. Pertama, nilai pendidikan karakter yang mencerminkan hubungan manusia dengan Tuhan, yang meliputi nilai; berdoa, beriman, dan bertaubat yang dikategorikan menjadi nilai pendidikan karakter religius. Kedua, nilai pendidikan karakter yang mencerminkan hubungan manusia dengan dirinya sendiri, yang mencakup nilai;
\end{abstract}


disiplin, demokratis, kreatif, kerja keras, dan semangat kebangsaan. Ketiga, nilai pendidikan karakter yang mencerminkan hubungan manusia dengan masyarakat, yang mencakup nilai; jujur, rasa ingin tahu, peduli sosial, toleransi, tanggung jawab, komunikatif, disiplin, dan kreatif. Keempat, nilai pendidikan karakter yang mencerminkan hubungan manusia dengan lingkungan, yang meliputi komunikatif dan peduli lingkungan. 2) Terdapat relevansi novel Kiai Ibrahim dan Tempat-Tempat Ibadat karya Akhmad Dimyati terhadap materi pembelajaran di sekolah, sehingga dapat digunakan sebagai bahan rujukan dalam kegiatan literasi materi pembelajaran sastra pada siswa SMA.

Kata Kunci: Novel, Kiai Ibrahim dan Tempat-Tempat Ibadat, pendidikan karakter, pembelajaran sastra

\section{PENDAHULUAN}

Pendidikan karakter atau pendidikan yang berbasis pada pembangunan karakter merupakan isu yang selalu dibicarakan, baik dalam dunia pendidikan, maupun di kalangan masyarakat pada umumnya. Pendidikan karakter dapat menuntun seseorang untuk memberikan arahan kepada kepada seorang anak menuju ke fase kedewasaan, sehingga dapat mandiri dan bertanggung jawab, serta mampu bertindak sesuai pilihannya sendiri (Suyatno, 2012). Dalam hal ini substansi utamanya, yaitu anak atau siswa sebagai subjek, yang mengalami proses didik hingga menjadi insan yang mandiri dan bertanggung jawab atas segala tindakannya. Dengan demikian, pendidikan karakter dapat mencegah terjadinya penyimpang perilaku seorang anak (remaja) atau siswa dari sikap yang tidak terpuji menjadi sikap terpuji sesuai yang diharapkan dalam pendidikan. Seperti diketahui masa usia remaja merupakan masa yang labil. Mereka dapat berubahubah sesuai kondisi lingkungannya. Apabila lingkungannya baik, maka ia akan menjadi baik. Akan tetapi, jika kondisi lingkungan sekitarnya buruk, maka dapat membuat anak atau siswa mudah terpengaruh ke dalam pergaulan yang buruk. Dengan demikian, dapat berakibat runtuhnya nilai-nilai pendidikan karakter yang sedang ditanamkan dan dibangun oleh orang tua ataupun sekolah terhadap anak atau remaja tersebut.

Pendidikan karakter sangat berperan dalam mengembangkan kemampuan dan watak serta peradaban suatu bangsa sehingga bermartabat. Selain itu, pendidikan karakter dapat mencerdaskan anak atau siswa, sehingga anak menjadi manusia yang beriman, bertakwa kepada Tuhan Yang Maha Esa, berilmu, berakhlak mulia, kreatif, mandiri, dan bertanggung jawab (Kesuma, 2011). Menurut Ki Hadjar Dewantara, pendidikan merupakan daya upaya untuk memajukan budi pekerti (kekuatan batin), pikiran, jasmani anak-anak, selaras dengan alam dan masyarakatnya. Ideal, pendidikan merupakan proses persiapan generasi muda untuk menjalankan kehidupannya, dan memenuhi tujuan hidupnya. Oleh karena itu, perlu upaya untuk menanamkan nilai-nilai melalui sistem pendidikan dengan menitikberatkan pada pendidikan karakter. Hal ini senada dengan upaya pemerintah tentang pendidikan karakter.

Pendidikan karakter pada anak atau siswa perlu diterapkan di lingkungan rumah maupun di sekolah karena perlu diketahui terdapat berbagai problematika dalam kehidupan siswa. Problematika itu, di antaranya tentang ketidakjujuran, ketidakdisiplinan, dan kekerasan yang dilakukan oleh anak (remaja) atau siswa. 
Oleh karena itu, untuk membangun karakter individu siswa, dapat diimplementasikan dalam materi pembelajaran di sekolah. Salah satu upaya membangun karakter peserta didik, yakni melalui pemahaman dan penghayatan karya sastra. Dalam konteks ini, karya sastra dapat menjadi komponen untuk membangun karakter anak atau siswa (Wellek \& Warren, 2014). Suka atau tidak, saat ini dunia pendidikan dinilai hanya memburu dan mementingkan ranah akademik semata atau berupa nilai-nilai akademik, sehingga mengabaikan persoalan-persoalan yang menyangkut pendidikan karakter. Untuk itu, sastra dapat menjadi medium yang strategis untuk mewujudkan terciptanya siswa yang berkarakter. Karya sastra bisa digunakan sebagai media penyampaian pendidikan karakter kepada peserta didik. Salah satu genre sastra yang digunakan sebagai media adalah novel yang di dalamnya ditampilkan unsur karakter tokoh (penokohan) yang memiliki peran langsung menyampaikan kandungan isi novel kepada pembacanya. Oleh karena itu, cerminan karakter ataupun isi yang terkandung di dalam sebuah karya sastra itu terkadang dipandang sebagai contoh dari kehidupan masyarakat (Haryadi, 2012).

Pemahaman dan penghayatan akan sebuah karya satra di pandang perlu dilakukan oleh anak atau siswa karena dengan membaca karya sastra secara berkelanjutan, diharapkan dapat menemukan nilai-nilai pendidikan berkarakter yang berguna dalam kehidupannya sehari-hari. Berdasarkan karya sastra yang dibacanya, anak dapat mengetahui tentang sikap, dan tingkah laku tokoh-tokoh dalam karya satra, sehingga diharapkan dapat mengambil hikmah dan pesan-pesan yang disampaikan atau yang diamanatkan dalam karya satra tersebut. Dengan demikian, sebuah karya sastra dapat memengaruhi, membujuk, dan akhirnya mengubah sikap anak atau siswa yang membaca (Wellek \& Warren, 1995). Namun demikian, pemilihan karya sastranya, tentu disesuaikan dengan umur si pembacanya, hal ini karena terdapat banyak novel dewasa yang ditampilkan di media online yang tentunya dapat membuat anak dewasa sebelum umurnya (Sudarsana, 2006).

Karya sastra memegang peranan penting dalam implementasi pendidikan karakter. Sebuah karya sastra dapat dijadikan sebagai media belajar peserta didik sehingga diharapkan dapat mengembangkan perilaku jujur, disiplin, tanggung jawab, peduli, santun, ramah lingkungan, gotong royong, kerja sama, cinta damai, responsif, dan proaktif dengan cara mengapresiasi sastra untuk memperhalus budi pekerti peserta didik (Suyanto, 2009). Dengan demikian dapat dinyatakan bahwa karakter lebih merunjuk pada hasil dari proses penanaman nilai-nilai. Pada dasarnya, nilai-nilai terkait dengan pendidikan karakter bangsa sudah ada sejak lama. Misalnya, kebiasaan mengucapkan salam kepada orang tua atau guru saat datang dan pulang dari sekolah, membaca doa sebelum memulai suatu kegiatan seperti hendak belajar ataupun makan, maupun dalam permainan tradisional daerah, yang mengajarkan sportivitas dan toleransi. Namun demikian, sebagian dari itu sudah mulai memudar. Untuk itu, terdapat upaya membangun pendidikan karakter melalui kegiatan literasi, salah satunya dengan membaca karya sastra fiksi berupa novel.

Novel merupakan salah satu karya sastra yang dapat diandalkan dalam menanamkan nilai-nilai bagi generasi muda, terutama novel yang dibuat oleh si 
penulis yang menuliskan novelnya di ranah pendidikan ataupun budaya. Sehingga si pembaca bukan hanya menikmati dalam membacanya, tetapi juga memperoleh nilai-nilai karakter yang ada di dalamnya. Oleh sebab itu, novel menjadi salah satu pilihan agar anak (remaja) yang memiliki nilai-nilai positif. Dengan demikian, mereka akan peka terhadap masalah-masalah yang berkaitan dengan kehidupan sosial serta dapat membentuk karakter yang baik untuk mencapai tujuan hidup dalam kehidupan sehari-hari.

Novel yang berjudul Kiai Ibrahim dan Tempat-Tempat Ibadat karya Akhmad Dimyati, layak dipilih dan dapat menjadi perantara yang strategis untuk mewujudkan tujuan menanamkan pendidikan karakter terhadap siswa ataupun peserta didik. Melalui novel yang berjudul Kiai Ibrahim dan Tempat-Tempat Ibadat karya Akhmad Dimyati, peserta didik (terutama tingkat SMA) dapat menambah wawasannya, serta bisa melakukan olah rasa, olah batin, dan olah budi secara kontinu sehingga secara tidak langsung mereka akan memiliki perilaku dan kebiasaan positif melalui proses apresiasi dan berkreasi melalui karya sastra.

Pemilihan novel Kiai Ibrahim dan Tempat-Tempat Ibadat karya Akhmad Dimyati dilatarbelakangi oleh adanya keinginan untuk memahami nilai pendidikan karakter yang terdapat dalam novel tersebut. Novel Kiai Ibrahim dan Tempat-Tempat Ibadat karya Akhmad Dimyati mempunyai nilai didik positif, yaitu penjelasan mengenai nilai pendidikan karakter yang terkandung dalam cerita sehingga dapat dijadikan masukan bagi penikmat atau pembacanya.

Setelah menyelami isi dari novel Kiai Ibrahim dan Tempat-Tempat Ibadat karya Akhmad Dimyati penulis menemukan nilai-nilai pendidikan karakter yang dapat menjadi cerminan dalam kehidupan sehari-hari. Dalam hal ini penulis akan membahas nilai pendidikan karakter berdasarkan novel tersebut.

\section{METODE}

Penelitian ini menggunakan pendekatan kualitatif sering disebut jenis penelitian naturalistik, karena penelitiannya dilakukan secara langsung pada objeknya. Jenis penelitian kualitatif ini digunakan untuk mendapatkan data yang mendalam, suatu data yang mengandung makna. Makna yang terkandung didalamnya, dan yang sebenarnya. Oleh karena itu, dalam penelitian kualitatif tidak menekankan pada generalisasi, tetapi lebih menekankan pada makna (Moleong, 2010).

Fokus penelitiannya adalah terkonsentrasi pada "Aspek Pendidikan Karakter dalam Kiai Ibrahim dan Tempat-Tempat Ibadat serta Relevansinya terhadap Materi Pembelajaran Sastra di SMA, yang terdapat dalam novel tersebut. Kemudian, diuraikan dalam bentuk kata-kata (deskriptif), bukan dengan angkaangka. Dalam penelitian ini menggunakan aspek karakteristik dalam novel tersebut sehingga dibatasi pada nilai karakter yang dapat diambil dari penokohahannya saja. 


\section{HASIL DAN PEMBAHASAN}

\section{Hasil}

Penelitian novel Kiai Ibrahim dan Tempat-Tempat Ibadat merumuskan dua permasalahan, yaitu nilai pendidikan karakter yang terkandung dalam novel Kiai Ibrahim dan Tempat-Tempat Ibadat dan Relevansi nilai Pendidikan Karakter terhadap Materi Pembelajaran Sastra di SMA. Pada novel Kiai Ibrahim dan Tempat-Tempat Ibadat banyak mengandung nilai toleransi yang diangkat oleh Akhmad Dimyati. Nilai-nilai tersebut secara umum diungkapkan secara tidak langsung dalam suatu jalinan cerita yang memusatkan Kiai Ibrahim sebagai tokoh utama.

Berdasarkan penelitian terhadap novel Kiai Ibrahim dan Tempat-Tempat Ibadat, terdapat beberapa temuan pendidikan karakter. Berikut ini merupakan disajikan dalam bentuk tabel temuan pendidikan karakter yang terdapat dalam novel tersebut.

Tabel 1. Temuan Pendidikan Karakter dalam Novel Kiai Ibrahim dan Tempat-Tempat Ibadat Karya Akhmad Dimyati

\begin{tabular}{|c|c|c|c|}
\hline No. & $\begin{array}{c}\text { Konteks Pendidikan } \\
\text { Karakter }\end{array}$ & $\begin{array}{l}\text { Nilai Pendidikan } \\
\text { Karakter }\end{array}$ & Halaman \\
\hline \multirow[t]{3}{*}{1.} & Manusia dengan Tuhan & Berdoa (Religius) & 24 \\
\hline & & Beriman (religious) & \\
\hline & & $\begin{array}{l}\text { Bersyukur } \\
\text { (Religius) }\end{array}$ & $\begin{array}{l}82,169,208 \\
101,127,145,347\end{array}$ \\
\hline \multirow[t]{5}{*}{2.} & $\begin{array}{l}\text { Manusia dengan Dirinya } \\
\text { Sendiri }\end{array}$ & Disiplin & 153 \\
\hline & & Kreatif & $9,51,137,216$ \\
\hline & & Kerja Keras & 184 \\
\hline & & Tanggung Jawab & 9 \\
\hline & & Gemar Membaca & $90,229,254$ \\
\hline \multirow[t]{4}{*}{3.} & Manusia & Jujur & $22,182,223$ \\
\hline & & Rasa Ingin Tahu & $24,43,45$ \\
\hline & & Peduli Sosial & \\
\hline & & Toleransi & $\begin{array}{l}61 \\
31,115,270\end{array}$ \\
\hline
\end{tabular}




\begin{tabular}{|c|c|c|c|c|}
\hline & & & Komunikatif & $3,28,31,178$ \\
\hline 4. & $\begin{array}{l}\text { Manusia } \\
\text { Lingkungan }\end{array}$ & dengan & $\begin{array}{l}\text { Semangat } \\
\text { Kebangsaan } \\
\text { Peduli Lingkungan }\end{array}$ & $\begin{array}{l}30 \\
171,208\end{array}$ \\
\hline
\end{tabular}

Pada tabel di atas, memperlihatkan bahwa nilai pendidikan karakter dalam novel Kiai Ibrahim dan Tempat Ibadat dalam konteks hubungan manusia dengan Tuhan terdapat 8 kutipan yang menunjukkan nilai pendidikan karakter religius dengan wujud karakter berdoa sebanyak 1 kutipan, beriman 3 kutipan, dan bersyukur 4 kutipan. Konteks hubungan manusia dengan dirinya sendiri terdapat 10 kutipan, yang menunjukkan nilai pendidikan karakter disiplin 1 kutipan, kreatif 4 kutipan, kerja keras 1 kutipan, tanggung jawab 1 kutipan, gemar membaca 3 kutipan. Konteks hubungan manusia dengan masyarakat terdapat 16 kutipan, yang mencakup nilai pendidikan karakter jujur 3 kutipan, rasa ingin tahu 3 kutipan, peduli sosial 1 kutipan, toleransi 3 kutipan, demokratis 2 kutipan, komunikatif 4 kutipan, semangat kebangsaan 1 kutipan. Konteks manusia dengan lingkungan terdapat 2 kutipan yang mencakup nilai pendidikan karakter peduli lingkungan. Artinya, novel ini memiliki nilai-nilai pendidikan karakter dan dapat digunakan oleh siswa SMA.

\section{Pembahasan}

Nilai Pendidikan karakter dalam novel Kiai Ibrahim dan Tempat-Tempat Ibadat terbagi menjadi empat kriteria, yaitu nilai pendidikan karakter antara manusia dengan Tuhan, nilai pendidikan karakter antara manusia dengan dirinya sendiri, nilai pendidikan karakter manusia dengan masyarakat, nilai pendidikan karakter manusia dengan lingkungan. Pembahasannya berikut:

\section{Nilai Pendidikan Karakter antara Manusia dengan Tuhan}

Nilai pendidikan karakter yang mencerminkan hubungan antarmanusia dengan Tuhan dalam novel Kiai Ibrahim dan Tempat-Tempat Ibadat mencakup nilai berdoa, beriman, dan bersyukur.

1. Berdoa

Doa memberikan kekuatan pada jiwa manusia di samping setiap usaha yang dilakukannya, selama di jalan yang benar. Setiap usaha manusia diiringi dengan doa yang ditujukan untuk memohon kemurahan dan keselamatan dari Tuhan. Berdoa wajib diterapkan dalam pembelajaran, baik sebelum maupun sesudah kegiatan pembelajaran tersebut. Tujuannya agar kegiatan pembelajaran yang kita jalani lancar dan diridhoi oleh Allah SWT.

"Dalam rumusanku, seseorang yang menghadapi kesulitan ataupun ketidakadilan dalm bekerja, jangan pusing memikirkannya. Ikuti saja irama yang ada, jangan berbuat yang destruktif ataupun murka. Paling pahit adalah dengan keluar atau mundur dari pekerjaan. Sambil terus 
berdoa memohon pertolongan Allah maka pertolongan itu akan datang tidak disangka." (Dimyati, 2018: 24)

\section{Beriman}

Ketika kita beriman, mempunyai ketetapan hati, mempunyai keyakinan dan kepercayaan pada Tuhan Yang Maha Esa niscaya hidup kita akan terasa lebih tenteram. Banyak hal yang nantinya akan kita alami, entah itu kebahagiaan maupun kesedihan. Berbekal iman yang kuat, maka peserta didik akan dapat merasakan besarnya manfaat beriman dalam setiap pembelajaran yang diikuti. Selain itu, beriman dalam pendidikan karakter termasuk ke dalam kategori religius, yang membuat peserta didik mempelajari sesuatu berdasar agama.

"Tiap sore habis Ashar ada anak-anak belajar mengaji, kecuali hari Minggu. Nah, kebetulan malam ini malam Jumat, ada Yasinan dan Tahlil di masjid," jawab Pak Rajab. (Dimyati, 2018: 82).

3. Bersyukur

Bersyukur termasuk dalam pendidikan karakter religius. Bersyukur dilakukan manusia kepada Tuhan sebagai ungkapan manusia berterima kasih atas apa yang diberikan oleh Tuhan. Jika manusia itu pandai bersyukur, maka akan merasakan nikmat atau seuatu yang telah diberikan oleh Tuhan sebagai anugerah yang wajib disyukuri. Manfaat bersyukur bagi peserta didik adalah mereka mampu menyadari bahwa apa yang telah diberikan oleh Tuhan merupakan nikmat dan anugerah yang diberikan. Selain itu, dengan mengajarkan bersyukur pada peserta didik, sama artinya dengan menanamkan pendidikan karakter religius. Seperti halnya dua kutipan berikut ini.

"Seharusnya orang pada bersyukur di Indonesia tumbuh budaya luhur, dalam arti membangun nilai-nilai luhur yang disebut nilai illahiyyah, nilai logika, etika dan estetika. (Dimyati, 2018: 101)

"Alhamdulillah... Akhirnya saya keturutan makan gudeg Yogjakarta," teriak Sobri ketika baru makan beberapa sendok. (Dimyati, 2018: 127)

\section{Nilai Pendidikan Karakter yang Mencerminkan Hubungan antara Manusia dengan Dirinya Sendiri}

Nilai pendidikan karakter yang mencerminkan hubungan antaramanusia dengan dirinya sendiri dalam novel Kiai Ibrahim dan Tempat-Tempat Ibadat meliputi disiplin, kreatif, kerja keras, tanggung jawab, dan gemar membaca.

1. Disiplin

Disiplin merupakan satu kata yang wajib untuk dipelajari oleh peserta didik. Disiplin merupakan sikap batin kita yang patuh dan taat pada peraturan atau hukum. Tujuan bersikap disiplin, yaitu membuat peserta didik dapat menghargai hidup dengan lebih baik. Apabila kita disiplin, maka semua pekerjaan akan berjalan dengan baik. Seperti berikut ini, Pak Hartono selalu disiplin membersihkan patung di gereja.

"Apakah patung-patung ini selalu dirawat?" Tanya Kiai Ibrahim.

"Dirawat dan dibersihkan," jawab Pak Hartono. 
"Ini saya sedang mencocokkan antara catatan dengan kondisi riil yang ada. Ternyata sempurna,” ucap Kiai Ibrahim. (Dimyati, 2018:153).

\section{Kreatif}

Sebagai peserta didik, sifat dan sikap kreatif sangat kita perlukan dalam segala hal. Tujuannya agar hal biasa yang dijalani oleh peserta didik menjadi lebih bermakna, misalnya saja seperti mencatat, jika hanya menggunakan pulpen warna hitam mungkin akan membosankan, tetapi jika menggunakan sisi kreatif, kita dapat menggunakan pulpen warna agar catatan kita lebih menarik untuk dibaca. Menjadi manusia yang kreatif membuat kita mampu menemukan dan merasakan hal baru yang orang lain belum rasakan atau mengubah hal-hal lama menjadi hal yang baru dan lebih menarik. kemampuan untuk dapat menjadi kreatif selalu ada dalam setiap orang, oleh karena itu, kita harus selalu berusaha mencari sisi kreatif dalam diri kita, melatihnya, dan mengembangkannya setiap saat. Berikut ini contoh kegiatan kreatif dalam novel Kiai Ibrahim dan Tempat-Tempat Ibadat.

"Gak susah. Itu bisa dimasukan plastik, singkong dan jagung jadi 1 tinggal di tenteng. Plastiknya gak diikat sebab masih panas," Sambung Bu Niknok. (Dimyati, 2018: 9)

"Bikin singkong kisat (kering) itu gampang, Bu. Setiap memasukan singkong atau apapun yang akan digoreng, kondisi minyak harus benar-benar tua. Jadi tidak boleh mengangkat gorengan, langsung masuk yang baru. Harus jeda sampai minyak benar-benar ngebul. Itu artinya minyak sudah tua," ujar Pak Urip. (Dimyati, 2018: 51)

"Wah salah Pak Kiai Ibrahim, harus berdiri baru berbicara. Terus tangan Gareng jangan lupa harus nekuk ke atas sambil nudingnuding," Pak Urip memberi penjelasan.

"Betul, lupa. Baik saya praktikkan," ucap Kiai Ibrahim sambil berdiri, kemudian bergaya dan berbicara layaknya karakter tokoh petruk. (Dimyati, 2018:137)

"Berarti orang-orang di sini hebat juga bisa membuat pura dan candi, ucap Kiai Ibrahim.

"Oh, tidak, Pak. Bahan-bahan candi dan pura dibuat di Bali, kemudian dirakit di sini," ucap ketut tegas. (Dimyati, 2018: 216)

\section{Kerja Keras}

Kerja keras merupakan usaha sepenuh hati dan sekuat tenaga untuk mendapatkan keinginan pencapaian hasil yang maksimal pada umumnya. Kerja keras adalah salah satu cara yang dapat digunakan jika sesuatu hal ingin dicapai. Bagi peserta didik tentunya hal ini sangat berkaitan dengan pembelajaran sehari-hari, dengan kerja keras dalam belajar mereka mampu mendapatkan nilai baik serta menggapai cita-cita yang telah diimpikannya. Hal ini juga tampak ketika Ari berusaha berusaha mempelajari 'Ogel' alat musik antik selama 2 tahun. 
"Sudah 1 tahun saya mahir pegang Orgel tersebut. Dan itu membutuhkan 2 tahun untuk berlatih," jelas Ari singkat. (Dimyati, 2018: 148)

Semua makhluk hidup di dunia butuh kerja keras walapun kerja keras tidak tiap harinya dilakukan makhluk hidup. Oleh karena itu, marilah kita menerapkan hidup bekerja keras, dengan maksimal dengan tujuan yang positif sesuai dengan tujuan yang ingin kita capai saat ini.

4. Gemar Membaca

Gemar membaca merupakan poin penting yang harus diterapkan pada peserta didik. Gemar membaca merupakan hal positif yang dapat menambah pengetahuan peserta didik. Hal ini seperti yang contohkan dua kutipan Kiai Ibrahim, di manapun ia berada, ia selalu dapat menjelaskan dan menjadikan referensi ilmu pengetahuanya. Berikut ini kutipan gemar membaca referensi sehingga dapat menjelaskan sesuatu yang belum diketahui oleh orang lain.

"Beliau adalah tokoh agama yang dikenal karena keahliannya dalam ilmu kasyaf, seorang alim dan memiliki keluhuran budi pekerti yang secara langsung dirasakan oleh masyarakat luas," jawab Kiai Ibrahim mencoba membuat konstruksi sejarah yang belum lama dibacanya. (Dimyati, 2018: 80)

"Ada catatan-catatannya yang berumur tua. Pada pokoknya anak Prabu Siliwangi dari isiri ke-1 Ratu Kentring Manik menjadi penerus tahtah di Pajajaran. Adapun anak dari istri ke-2 Ratu Subang Larang berkiprah di Cirebon.Awalnya Pangeran Walangsungsang menajdi adipati Pakungwati di Cirebon bergelar Pangean Cakrabuana. Hal ini setelah kepulangannya selam 3 tahun di Mesir krtiks menyertai Nyai Lara Santang yang dipersunting oleh Sultan Mesir sewaktu ibadah haji," Ucap Kiai Ibrahim. (Dimyati, 2018: 229)

\section{Nilai Pendidikan Karakter yang Mencerminkan Hubungan antara Manusia dengan Masyarakat}

Nilai pendidikan karakter yang mencerminkan hubungan antara manusia dengan masyarakat dalam novel Kiai Ibrahim dan Tepat-Tempat Ibadat meliputi sikap jujur, rasa ingin tahu, peduli sosial, demokratif, komunikatif, toleransi, dan semangat kebangsaan.

1. Jujur

Manusia yang baik adalah manusia yang selalu berkata jujur. Bagi yang telah mengenal kata jujur mungkin sudah tahu apa itu arti atau makna dari kata jujur tersebut. Apalagi sebagai seorang peserta didik yang mematuhi aturan, bersikap jujur adalah wajib. Setelah memahami makna jujur, maka peserta didik dapat menyikapi sebuah permasalahan yang dihadapi. Selain itu dengan bersikap jujur, mampu menjadikan peserta didik sebagai seseorang yang dapat dipercaya di kemudian hari.

"Itu Pak Kiai Ibrahim, saya itu kadang menghadapi masalah dalam ruang kerja. Saya sudah bekerja sebaik mungkin, tapi kok malah dimusuhi oleh teman-teman kerja. Tidak banyak, ada beberapa orang, 
yang memancing-mancing konflik. Itu bagaimana, Pak." (Dimyati, 2018: 22)

"Maaf Pak Kiai Ibrahim, sebagai umat Hindu saya mempelajari sejarah candi-candi Hindu. Melihat foto-fotonya, tapi kalau melihat langsung, belum," ucap ketut polos. (Dimyati, 2018: 223)

Bersikap jujur memerlukan keberanian yang lebih. Keberanian untuk tidak berkata bohong, maupun keberanian untuk tidak menyakiti perasaan orang lain. Seperti halnya Ketut yang dengan berani berkata jujur belum pernah melihat candi-candi Hindu meskipun ia seorang pemeluk agama Hindu.

\section{Rasa Ingin Tahu}

Rasa ingin tahu sering dialami oleh peserta didik ketika mereka mempunyai atau mengalami suatu pengalaman dan pembelajaran baru, yang sebelumnya belum pernah mereka dapatkan. Hal ini baik dalam pembelajaran, karna mampu meningkatkan pengetahuan siswa. Di dalam novel KIai Ibrahim dan Tempat-Tempat Ibadat, terdapat beberapa contoh ungkapan rasa ingin tahu yang dilontarkan oleh tokoh-tokoh di dalamnya.

"Emang Pak Kiai Ibrahim kadang menghadapi masalah juga dalam bekerja?" tanya Sobri, tamu yang termuda.

"Saya bekerja setiap hari bukannya tanpa masalah. Meskipun masalah tidak timbul dalam tempat kerja," ucap Kiai Ibrahim. (Dimyati, 2018: 24)

"Kalau boleh nanya Pak Kiai Ibrahim ya, itu yang dibilang kok Pak Urip itu Islam Kejawen. Seperti apa kejawen itu?" Tanya Sobri Aromanis agak serius.

"Sederhananya begini dik Sobri ya, jika Anda mengatakan sesuatu tentang kebaikan, maka semua itu ad pada kultur Jawa atau Kejawen itu. Maksudku, kejawen tidak lain adalah merupakan ajaran-ajaran kebaikan dalam kehidupan." (Dimyati, 2018: 43)

"Maaf kalau boleh tahu, seberapa jauh kejawen mempengaruhi agamaagama. Barangkali Pak Kiai Ibrhim tahu, "Tanya Sobri lebih jauh.

"Kejawen adalah istilah umum berisikan tentang seni, budaya, tradisi, ritual, sikap serta filosofi orang-orang jawa. Kejawen juga merupakan pada sebuah etika dan sebuah gaya hidup yang dilhami oleh pemikiran Jawa," jawab Kiai Ibrahim. (Dimyati, 2018: 45)

\section{Peduli Sosial}

Peduli merupakan kemauan untuk memberi baik berupa perhatian, maupun waktu, bantuan pikiran, waktu, tenaga dan sebagainya. Jika dikaitkan dengan peserta didik tentu saja hal ini sangat berkaitan satu sama lain. Dengan bersikap peduli, peserta didik mampu memotivasi diri untuk lebih mengerti keadaan sekitar. Peduli juga tidak menghitung-hitung keuntungan atau balasan apapun yang akan diterima selanjutnya. 
"Coba bandingkan dengan gaya hidup dugem, dansa-dansi ataupun hobi musik yang membuat pekak telinga. Lebih parah lagi gaya hidup mabuk-mabukan atau narkoba. Itu gaya hidup yang banyak mudharat daripada manfaat. Menjauhi spiritualis maupun sosiolitas. Otomatis orang yang mau ruwatan itu akan menjauhi radikalisme ataupun narkoba." (Dimyati, 2018: 61)

\section{Toleransi}

Toleransi merupakan sikap saling menghargai satu sama lain. Toleransi baik diterapkan pada peserta didik, agar peserta didik mampu menghargai satu sama lain, seperti beberapa petikan Kiai Ibrahim berikut ini.

"Untuk mengatasi dekadensi moral, diperlukan penguatan dalam mengamalkan ajaran agama oleh para pemeluknya. Juga kudu dilakukan pendekatan antarumat beragama agar supaya terjadi kerukunan dan tolong menolong dalam hal kebaikan. Dengan demikian, agama dirasakan sebagai garda terdepan dalam mengatasi disintegrasi sosial dan dekadensi moral. Masyarakat boleh mengawali dan aktif di dalamnya tanpa menunggu pemerintah. Begitulah yang saya maksudkan, Pak," ucap Kiai Ibrahim. (Dimyati, 2018: 31)

"Memangnya Pak Kiai Ibrahim punya misi atau punya massage?" tanya Jalal.

"Bukannya misi atau massage, melainkan obsesi, ingin mengalami langsung berada di tengah-tengah orang menjalankan ibadah dari semua tempat peribadatan. Dengan demikian, saya merasakan betapa mereka melaksanakan ibadah dengan ketenangan dan kedamaian. Lalu berkomunikasi dengan jamaah mereka, sekadar saling mengenal dan berbincang tentang kebersamaan dan keagungan orang beragama," jawab Kiai Ibrahim. (Dimyati, 2018:114-115)

\section{Demokratis}

Sifat demokratis bagi peserta didik perlu ditanamkan, agar siswa dapat lebih bijaksana ketika mengemukakan pendapat maupun ketika berdiskusi. Hal ini juga terlihat dalam novel Kiai Ibrahim dan Tempat-Tempat Ibadat terlihat ketika Kiai Ibrahim berkata pada Bu Niknok (bagian konsumsi) dan temannya di Saung Rumah Batu.

"Pingin usul Pak Kiai Ibrahim, itu singkong dan jagung manis kalau direbus semua boleh, gak? Biar dibagi habis kepada penonton daripada disisakan," tanya Bu Niknok.

"Nanti baginya susah, gak?" Tanya Kiai Ibrahim. (Dimyati, 2018: 9)

"Ulama se-dunia sepakat menambah-nambah sesuatu dalam agama itu dosa...." ucap Kiai Ibrahim.

"Saya kira dalam beragama harus berkata, ini pendapatku dan bagaimana pendapatmu ya silakan laksanakan dan dipertanggungjawabkan di akhirat. Terlebih pada soal furu'iyah dan ghairu mahdhah. Bagaimana menurut Pak Kiai Ibrahim, betul gak?" Tanya Pak Urip mengakhiri kalimatnya. 
"Betul...betul...betul," jawab Kiai Ibrahim singkat. (Dimyati, 2018: 95)

Berdasarkan kutipan tersebut memberikan contoh bahwa setiap usulan yang diberikan oleh siapapun, sebaiknya sebagai pembelajaran diskusi, maka peserta didik harus menerima berbagai usulan yang dilontarkan dan belajar menerima perbedaan pendapat.

6. Komunikatif

Komunikatif adalah suatu cara agar membentuk suatu hubungan kmunikasi antara peserta didik satu dan yang lainnya. Hal ini dapat dilatih dengan membrikan tugas kelompok, berdiskusi, maupun dengan hal lainnya. Hal ini seperti yang dicontohkan dalam petikan berikut.

"Sabar...sabar... dengar dulu sahabat-sahabatku. Siapa bilang ini musykil? Pekerjaanku tiap hari ke kota, sampeyan tentu tahu, kan! Ternyata di kota orang berbicara soal sponsor... sponsor... sponsor ... itu lho perusahaan-perusahaan besar nanti pasang spanduk, umbulumbul dan menampilkan produk-produknya di arena Plorodan dan wayang, maka mereka akan memberikan dana. (Dimyati, 2018: 3)

"Begini Pak Urip," ucap Kiai Ibrahim.

"Saya itu ingin berkunjung ke tempat-tempat ibadat orang lain, macam klenteng, vhara, gereja. Pingin melihat lebih dekat dan mengajak mereka ngobrol-ngobrol, supaya saling kenal begitu," ucap Kiai Ibrahim.

Saya datang ke sini perlunya mengajak Pak Urip, kapan-kapan saya ajak berkunjung ke kelenteng, ke pure, dan gereja ketika banyak jemaat pada menghadiri ritual agamanya. Yah paling kita lihat-lihat dan ngobrol-ngobrol sama mereka."

"Boleh, asalkan tidak mendadak, karena diperlukan persiapan juga, jawab Pak Urip. (Dimyati, 2018: 28)

\section{Semangat Kebangsaan}

Semangat kebangsaan merupakan satu hal yang harus dimiliki oleh peserta didik. Di dalam pembelajaran, hal ini dapat memacu minat belajar peserta didik sehingga nantinya mendapatkan hasil belajar yang maksimal. Selain itu, mengingatkan akan pentingnya saling bekerja sama dan bertoleransi antarumat beragama. Seperti halnya yang dilakukan Kiai Ibrahim ketika menjelaskan masalah kebangsaan kepada teman-temannya.

"Problem bangsa kita adalah menguatnya disintegrasi sosial. Contohnya, antarkampung pada tawuran. Terus, antarumat beragama tidak saling sapa, masimg-masing hanya berkelompok sendiri-sendiri. Ketika muncul radikalisme dari oknum-oknum tertentu, jadi menambah ketegangan atau saling curiga. Hal inilah yang membuat fondasi Negara kesatuan bisa makin rapuh. dari sisi lain, Pak Urip coba perhatikan masalah dekadensi moral. Contohnya, pejabat hobinya korupsi, masyarakat pada narkoba, muncul pula pelecehan dan kekerasan seksual di mana-mana. Nah, coba bayangkan ke depan 
bangsa ini mau jadi apa. Fondasinya buat berbangsa dan bernegara telah bertambah rapuh, betul gak, Pak?" jelas Kiai Ibrahim. (Dimyati, 2018: 30)

\section{Nilai Pendidikan Karakter yang Mencerminkan Hubungan antara Manusia dengan Lingkungan}

Peduli lingkungan bagi peserta didik baik untuk diterapkan karena hal ini bertujuan untuk memberikan rasa peka terhadap keadaan lingkungan sekitar, seperti yang ungkapkan dalam kutipan berikut ini.

"Kurasa pada saat orang berziarah pasti berkumpul dengan orang banyak. Lalu di sana kita pasti menerapkan kaidah-kaidah pergaulan. Misalnya, harus tenang, damai, sopan santun, dan saling menghormati. Juga utuk mengalami kedalaman persatuan dan persaudaraan dan doa bersama dengan umat Katolik lainnya. Inilah solidar sosial yang efektif, menjadi jaring pengaman sosial pada skala masif," jelas Kiai Ibrahim. (Dimyati, 2018: 171)

"Apakah setiap hari Minggu di sini selalu ramai?" Tanya Kiai Ibrahim. "Betul selalu ramai, di luar pura banyak dikunjungi wisatawan. Hari Minggu ini lebih ramai dari biasanya, karena nanti malam ada ritual Purwani, ujar Ketut Suarka. ( Dimyati, 2018: 208)

Dalam kedua petikan tersebut dijelaskan bagaimana para pengunjung (umat Khatolik) yang akan berziarah ke Goa Maria sangat tertib meskipun cukup ramai. Kemudian, pada petikan kedua dijelaskan diungkapkan bahwa bahwa Pura Parahyangan di Kaki Gunung Salak, Bogor tempatnya akan selalu ramai jika di hari Minggu. Masyarakat yang hadir bukan saja yang akan sembahyang, namun juga para wisatawan.

Berdasarkan pembahasan tersebut menunjukkan bahwa novel Kiai Ibrahim dan Tempat-Tempat Ibadat karta Akhmad Dimyati dapat digunakan sebagai bahan pembelajaran sastra di SMA serta dapat dimasukan ke dalam kegiatan literasi pembelajaran sastra, sehingga siswa memiliki rasa peka terhadap karya sastra dan nilai-nilai pendidikan karakter yang terkandung di dalamnya.

\section{SIMPULAN}

Berdasarkan hasil penelitian terhadap novel Kiai Ibrahim dan TempatTempat Ibadat Karya Akhmad Dimyati yaitu: 1) Nilai pendidikan karakter dalam novel Kiai Ibrahim dan Tempat-Tempat Ibadat Karya Akhmad Dimyati dibedakan menjadi empat kriteria. Pertama, nilai pendidikan karakter yang mencerminkan hubungan manusia dengan Tuhan, yang meliputi nilai; berdoa, beriman, dan bertaubat yang dikategorikan menjadi nilai pendidikan karakter religius. Kedua, nilai pendidikan karakter yang mencerminkan hubungan manusia dengan dirinya sendiri, yang mencakup nilai; disiplin, demokratis, kreatif, kerja keras, dan semangat kebangsaan. Ketiga, nilai pendidikan karakter yang 
mencerminkan hubungan manusia dengan masyarakat, yang mencakup nilai; jujur, rasa ingin tahu, peduli sosial, toleransi, tanggung jawab, komunikatif, disiplin, dan kreatif. Keempat, nilai pendidikan karakter yang mencerminkan hubungan manusia dengan lingkungan, yang meliputi komunikatif dan peduli lingkungan. 2) Terdapat relevansi novel Kiai Ibrahim dan Tempat-Tempat Ibadat karya Akhmad Dimyati terhadap materi pembelajaran sastra di SMA, sehingga dapat digunakan sebagai bahan rujukan dalam kegiatan literasi materi pembelajaran sastra pada siswa SMA.

\section{DAFTAR PUSTAKA}

Dimyati, A. (2018). Kiai Ibrahim dan tempat-tempat ibadat. Yogyakarta: Penerbit Deepublish.

Haryadi. (2012). Peran sastra daam pembentukan karakter bangsa. http://publiksastra.net/peran-sastra-dalam-pembentukan-karakter-bangsa2/. Diunduh pada 7 Januari 2020.

Kesuma, D. (2011). Pendidikan karakter kajian teori dan praktek di sekolah. Bandung: Remaja Rosdakarya.

Moleong, L. J. (2010). Metodologi penelitian kualitatif. Bandung: Remaja Rosdakarya.

Sudarsana, G. (2006). Pengajaran sastra dan pornografi. Diakses dari http://minifica.net/nmview. Diunduh pada 9 Februari 2020.

Suyatno. (2012). Peran pembelajaran bahasa dan sastra dan pendidikan karakter. Yogyakarta: Citra Aji Pratama.

Suyatno. (2009). Urgensi pendidikan karakter. Diunduh melalui http:// www. mandikdasmen.depdiknas.go.id/web/pages/urgensi.html.

Warren, A., \& Wellek, R. (1995). Teori kesusastraan. Jakarta: Penerbit PT Gramedia Pustaka Utama.

Wellek, R., \& Warren, A. (2014). Teori kesusastraan. Edisi Revisi. Jakarta: PT. Gramedia Pustaka Utama. 